\title{
Effect of TRH and TSH on Circulatory Glucose and Fatty Acids Responses in Hypoinsulenemic Male Dwarf Goats
}

\author{
Rubina Mushtaq ${ }^{1}$, Rehana Mushtaq1${ }^{1}$, Abdul Majeed Cheema ${ }^{2}$, Sobia Khwaja ${ }^{1}$ \\ ${ }^{1}$ Zoology Department, Federal Urdu University of Arts Science and Technology, Karachi, Pakistan \\ ${ }^{2}$ Institute of Molecular Biology and Biotechnology, The University of Lahore, Lahore, Pakistan \\ Email: mushtaqrehana@ymail.com
}

Received 28 August 2014; revised 5 October 2014; accepted 31 October 2014

Copyright @ 2014 by authors and Scientific Research Publishing Inc.

This work is licensed under the Creative Commons Attribution International License (CC BY). http://creativecommons.org/licenses/by/4.0/

(c) (i) Open Access

\begin{abstract}
Diabetes mellitus or hypoinsulinemia was induced successfully in the male dwarf goats aged between 2 - 3 years with 2 consecutive administrations of streptozotocin. A comparable group of intact control goats was also maintained. In ruminants including goats unlike non-ruminants, insulin generally displays ineffectiveness or resistance in their biochemical setup to facilitate gluconeogenesis, the only source of glucose in these animals. In present study almost in the absence of insulin through induced hypoinsulinemia the effects of thyrotropin releasing hormone (TRH) ( $30 \mu \mathrm{g} / \mathrm{kg}$ body weight) and thyroid stimulating hormone (TSH) $(2.5 \mu \mathrm{g} / \mathrm{kg}$ body weight) on circulatory glucose and different fatty acid fractions were studied in insulin resistant ruminant model. Fatty acid fractions were estimated by gas chromatography. Both TRH and TSH administration lowered glycemia in insulin deficient goats compared to the controls but significantly with TSH dose only. In intact goats the detectable circulating long chain fatty acids (LCFAs) fractions of lauric, myristic, palmitic, stearic, oleic and linoleic acid were undetected except linoleic acid in the hypoinsulinemic state, however were found restored following TRH and TSH administrations and some of LCFAs; stearic (6417\%), oleic (1676\%) and linoleic acid $(1225 \%)$ increased exceptionally with TSH dose. In Intact goats however the hormones variedly increased the fractions. The volatile fatty acid fractions (VFAs) of formic, acetic, propionic, iso-butyric, $n$-butyric, iso-valeric, $n$-valeric, iso-caproic, n-caproic and heptanoic acid were detected in the goats. The most VFAs fractions markedly increased in hypoinsulinemic goats compared to the control goats following TRH and TSH infusion. These results have indicated that endogenously stimulated thyroid hormones with TRH and TSH in insulin deficient state inhibit the mechanisms of utilizing the fatty acids in glucose production. Therefore the study reveals thyroid hormones inhibitory effects on gluconeogenesis in insulin resistance and hyperglycemia.
\end{abstract}

\section{Keywords}

Glucose, Goats, Induced Hypoinsulinemia, Long Chain Fatty Acids, Thyroid Stimulating Hormone, 


\section{Introduction}

There is a close relationship between the hypothalamus, the anterior pituitary and the thyroid gland. Hypothalamus is the source of the TRH that regulates TSH secretion from anterior pituitary. TSH is the major regulator of the morphologic and functional states of the thyroid and the secretion of T4 and T3 from the gland [1]. The administration of TRH and TSH elicits physiological stimulation of thyroid hormones compared to pharmacological administration of thyroid hormones and thus is preferred approach to studying the sensitive biochemical targets for thyroid hormones' actions.

Physiological mechanisms of insulin have been studied while destroying its source of beta cell of endocrine pancreas. Thus, hypoinsulinemic state is obtained for investigating the physiological responses in extreme insulin deficiency. Hypoinsulinemia for decades has been induced by beta cell destruction with cytotoxic streptozotocin [2].

Thyroid hormones affect metabolism extensively and have shown interactions with insulinon biochemical targets. Several specific effects of thyroid hormones on the insulin related metabolism are well understood. Hyperthyroidism in growing sheep modifies the ability of insulin to regulate metabolism [3]. The daily supplementation of low doses of KI that enhanced thyroid activity showed improved insulin sensitivity and decreased blood urea nitrogen in dairy goats [4]. The studies on relationship of diabetic or insulin insufficiency condition on thyroid responses had also been done broadly. Thyroidal secretory response to large doses of TSH decreased in uncontrolled diabetes mellitus [5]. Values for thyroxin (T4) and free triiodothyronine (T3) were significantly higher in non-diabetic than those in diabetic bulls [6].

The ruminants including sheep, camel etc. were studied for glucose and insulin responses and these all demonstrated insulin resistance [7]. In ruminants insulin resistance promotes glucagon action in enhanced gluconeogenesis from volatile fatty acids, the main products of rumen digestion. Probably ruminants' gluconeogenic increase is similar to the observation that elevated insulin resistance increased hepatic expression of key gluconeogenic genes in mice [8]. Propionate is proved and also reported as main product utilized for gluconeogenesis in the ruminants [9]. Therefore it is assumed that gluconeogenic genes are well expressed in ruminants due to insulin resistance adapted for special mode of rumen nutrition.

Considering hormonal interactions, in uncontrolled insulin resistant diabetes mellitus type 2 TSH level was reported altered [10]. Hypothalmo-hypophyseal and thyroid axis of sheep and goats is of a typical mammalian pattern as TRH administration induced sharp increases in plasma thyrotrophic and thyroid hormone levels in lambs [11]. Dahl et al. observed that thyroid hormones can act centrally to inhibit TRH (and thus TSH) release in the ewe, so supporting the concept that negative feedback action of thyroid hormones is partly exerted at the hypothalamic level in ruminants [12].

Recently there had been investigative trend on the effects of various hormones on metabolites in ruminants [13] and importance of short chain fatty acids in the genetic expression in type 2 diabetes and obesity, the disorderly states which render the insulin ineffective in action [14]. Hypoinsulinemia induced by beta cell destruction with cytotoxic streptozotocin [2] could be another condition of insulin absence to compare with the insulin resistance state for the observance of thyroid activity enhanced through hypothalamo-pituitary hormones on the various types of circulatory free fatty acids in the goats. Thus, the present study was conducted to observe the effects of thyroid regulatory hormones on the carbohydrate and specific lipid targets in a ruminant model of dwarf goat. The study may reveal information on the lipid metabolism in ruminants which may also provide useful information for insulin resistance type 2 diabetes.

\section{Material and Methods}

Adults male dwarf goats of about three years of age were kept in an intensive care. These were subjected to an organized feeding regime of green fodder as well as concentrate dry ration. Goats were acclimated for seven days. Goats were rendered diabetic (hypoinsulinemic), permanently, with two successive administrations of streptozotocin (STZ) (Sigma Chemical Company, USA) at a concentration of 33 and $40 \mathrm{mg} / \mathrm{kg}$ body weight in 
saline citrate buffer ( $\mathrm{pH} 4.3$ ) with in four days. The goats were administered with TRH (30 $\mu \mathrm{g} / \mathrm{kg}$ body weight) and TSH ( $2.5 \mu \mathrm{g} / \mathrm{kg}$ body weight) and blood sampling protocol is shown in Table 1 . Glycemia, long chain fatty acids and volatile fatty acids were estimated following hormonal administration in control and hypoinsulinemic goats.

Glucose was estimated with glucose oxidase method [15] and commercial kits (Randox Laboratories Ltd.) were used. The fraction of LCFAs were extracted from plasma by the method of Falholt et al. [16] and esterified with boron triflouride [17] and further extracted with benzene. Volatile fatty acids (VFAs) were estimated after the procedure of [18]. A standard mixture from Supelco, Inc. GC Bulletin 748H was used for gas chromatography.

\section{Results}

\subsection{Glycemia after TRH Dose}

Glycemia prior to the hormonal administration was $62.93 \pm 0.03$ and $139.2 \pm 19.3 \mathrm{mg} / \mathrm{dl}$ in intact and hypoinsulinemic goats respectively. In intact goats, the glucose level increased about $8 \%$ within an hour of the administration of the hormone. It remained elevated significantly from the pre-hormonal administration level up to 4 hours and thereafter was gradually restored almost to original level in 24 hours, In hypoinsulinemic goats glycemia rose almost $9 \%$ in 2 hours after the hormone dose and it was abruptly reduced below the pre-hormone administration level within four hours thereafter it returned almost to original level in 24 hours after the hormone dose. The glycemia was noticeably lower in hypoinsulinemic goats 4 and 8 hours after the hormone injection compare to the intact goats; however the difference was not significant statistically (Figure 1).

\subsection{Glycemia after TSH Dose}

Blood glucose level was $64.94 \pm 1.05$ and $158.64 \pm 23.6 \mathrm{mg} / \mathrm{dl}$ in intact and hypoinsulinemic groups respectively just before the hormone injection. It remained slightly elevated non-significantly one to 24 hours after the hormone dose in intact goats. In hypoinsulinemic goats however it elevated significantly within an hour from its pre dose level and gradually dropped non-significantly $13 \%$ up to 4 hours which persisted up to 24 hours compare to its original value. The glycemia was thus significantly reduced following TSH infusion in hypoinsulinemic compare to intact goats (Figure 1).

\subsection{TRH on Long Chain Fatty Acids}

The fractions of lauric $(0.7596 \mu \mathrm{g} / \mathrm{ml})$, myristic $(0.2862 \mu \mathrm{g} / \mathrm{ml})$, palmitic $(0.2646 \mu \mathrm{g} / \mathrm{ml})$, stearic $(0.2071 \mu \mathrm{g} / \mathrm{ml})$, oleic $(0.1867 \mu \mathrm{g} / \mathrm{ml})$ and linoleic acid $(0.1472 \mu \mathrm{g} / \mathrm{ml})$ were estimated just before hormone administration in the control goats. One hour post treatment slight reduction in lauric (10\%) and elevation in palmitic (14\%), stearic (33\%), oleic (11\%) and linoleic acid (38\%) was observed.

In insulin deficient goats, only linoleic acid $(0.0803 \mu \mathrm{g} / \mathrm{ml})$ was detected prior to hormone injection, however, within one hour after its administration all the fractions of lauric $(0.283 \mu \mathrm{g} / \mathrm{ml})$, myristic $(0.1601 \mu \mathrm{g} / \mathrm{ml})$, palmitic $(0.1147 \mu \mathrm{g} / \mathrm{ml})$, stearic $(0.393 \mu \mathrm{g} / \mathrm{ml})$ oleic $(0.2112 \mu \mathrm{g} / \mathrm{ml})$ and linoleic acid $(0.538 \mu \mathrm{g} / \mathrm{ml})$ were observed in the circulation. Insulin deficiency reduced most of the studied LCFAs to an undetectable concentration as these were adequately estimated in the intact goats. The appearance of undetected fractions of lauric, myristic, palmitic, stearic, and oleic acid in the hypoinsulinemic state had been found to be restored with TRH administration. It is obvious that TRH directly or indirectly interfered in the mechanism to restore these fractions that disappeared in insulin deficiency. It is a prominent result of the study. In intact goats the increases in the concentration of the most of the fractions following TRH infusion is a similar response as in hypoinsulinemic goats (Figure 2).

\subsection{TSH on Long Chain Fatty Acids}

All the studied fractions of lauric $(0.283 \mu \mathrm{g} / \mathrm{ml})$, myristic $(0.1601 \mu \mathrm{g} / \mathrm{ml})$, palmitic $(0.1147 \mu \mathrm{g} / \mathrm{ml})$, stearic $(0.393 \mu \mathrm{g} / \mathrm{ml})$ oleic $(0.2112 \mu \mathrm{g} / \mathrm{ml})$ and linoleic acid $(0.538 \mu \mathrm{g} / \mathrm{ml})$ had been estimated in considerable amounts before the hormone dose in the control intact goats. One hour after the hormone administration all the fractions increased conspicuously with marked elevation of $167 \%, 115 \%, 86 \%, 70 \%, 32 \%$, and $56 \%$ in lauric, myristic, 
Table 1. Sampling schedule following TRH and TSH administration.

\begin{tabular}{cc}
\hline Hormone infused & Time blood obtained after administration \\
\hline TRH & $0,15,30,60,120,240,480 \mathrm{~min}$, and $24 \mathrm{~h}$ \\
TSH & $0,30,60,120,240,360,480 \mathrm{~min}$, and $24 \mathrm{~h}$ \\
\hline
\end{tabular}
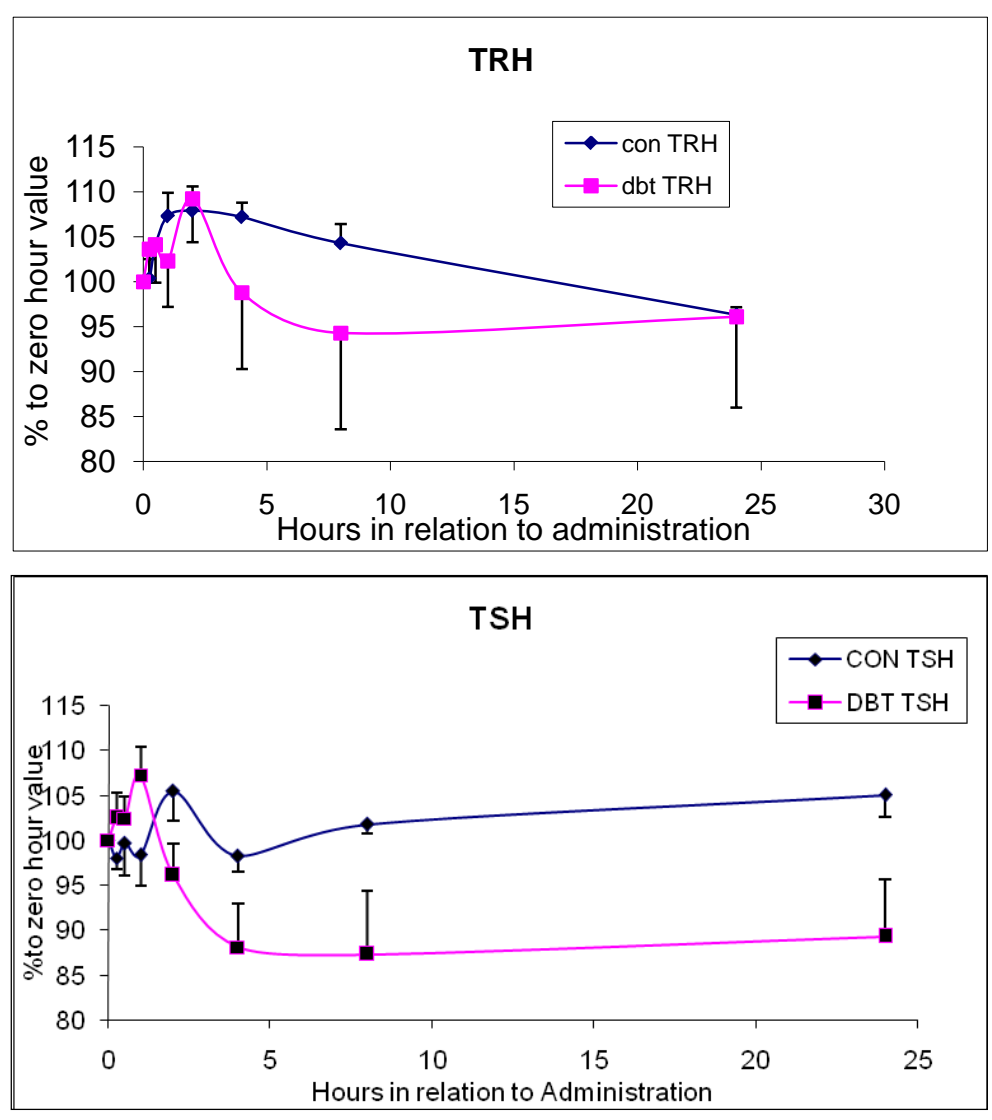

Figure 1. Plasma glucose following TRH (30 $\mu \mathrm{g} / \mathrm{kg})$ and TSH $(2.5 \mathrm{ng} / \mathrm{kg})$ administration in intact and streptozotocin induced diabetic goats. Con: Control or Intact goats; DBT: Diabetic or hypoinsulinemic goats.

palmitic, stearic, oleic and linoleic acid concentration respectively compared to pre dose corresponding values of the fractions.

In hypoinsulinemic goats, prior to TSH infusion fractions of lauric $(0.1445 \mu \mathrm{g} / \mathrm{ml})$, palmitic $(0.01845 \mu \mathrm{g} / \mathrm{ml})$ stearic $(0.044 \mu \mathrm{g} / \mathrm{ml})$, oleic $(0.0182 \mu \mathrm{g} / \mathrm{ml})$ and linoleic acid $(0.028 \mu \mathrm{g} / \mathrm{ml})$ were estimated. Except lauric the other detected fractions were in negligible amounts and myristic acid was not detected in pretreatment samples. In the samples obtained one hour after TSH administration myristic acid appeared in adequate amount $(0.2189$ $\mu \mathrm{g} / \mathrm{ml}$ ), lauric and palmitic acid also increased $139 \%$ and $112 \%$ respectively. The fractions of stearic (6417\%), oleic (1676\%) and linoleic acid (1225\%) thus increased many fold after treatment (Figure 2). The results of TSH dose are similar to that of TRH dose thus again are prominent results of the study.

\subsection{TRH on Volatile Fatty Acids}

All the fractions studied, of volatile fatty acids were detected in plasma of control and also in the hypoinsulinemic goats with the exception of n-caproic acid before the hormone treatments. In the control goats, the fractions of formic (48\%), n-butyric (14\%) and n-caproic acid (30\%) increased, acetic and heptanoic acid did not show a change whereas propionic (37\%), iso-butyric (25\%), iso-valeric (39\%), n-valeric (28\%) and iso-caproic (39\%) were reduced noticeably one hour post hormonal treatment. 

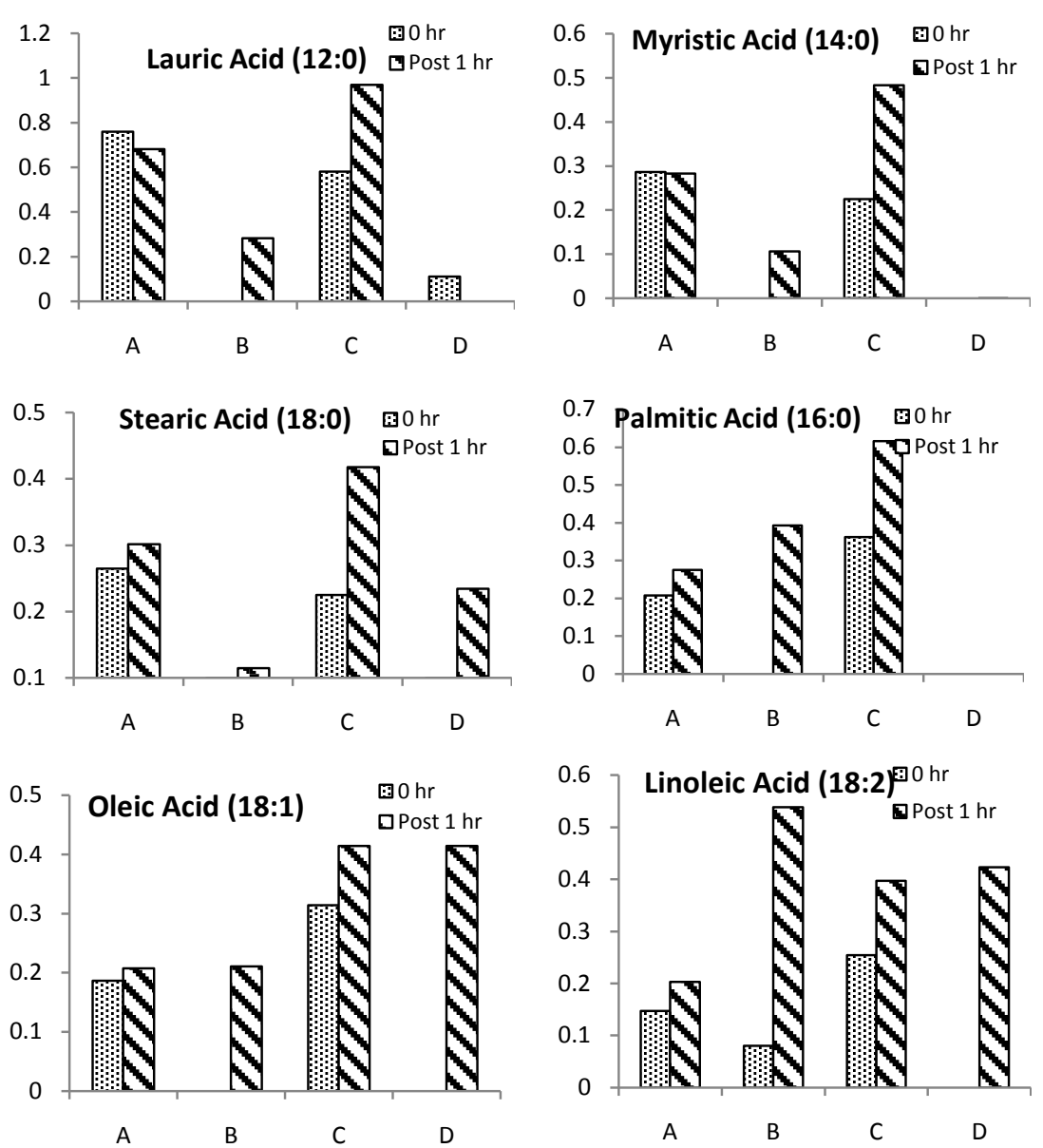

Figure 2. Plasma LCFAs ( $\mu \mathrm{g} / \mathrm{ml})$ before and 1 hour following TRH $(30 \mu \mathrm{g} / \mathrm{kg})$ and TSH (2.5 ng/kg) administration in intact and streptozotocin induced hypoinsulinemic. A: Control; B: TRH treated; C: Control; D: TSH treated.

In hypoinsulinemic goats, noticeable increase of formic (28\%) and pronounced elevations of n-butyric (250\%), iso-valeric (138\%) n-valeric (164\%) and iso-caproic acid (289\%) were observed whereas the fractions of acetic (30\%), propionic (35\%), iso-butyric (30\%) and heptanoic acid (7\%) were found to be lowered one hour after TRH injection. The fraction of n-caproic acid was not detected prior to and after the hormonal infusion in these goats (Figure 3).

The marked increases of the fractions of n-butyric (250\%), iso-valeric (138\%) n-valeric (164\%) and iso-caproic acid (289\%) in hypoinsulinemic goats specifically and overlooking to other variations concerning FFA in both intact and insulin deficient groups explicate that there is a possibility of the contribution of these VFAs fractions in greater elevation of total free fatty acids in the hypoinsulinemic goats.

\subsection{TSH on Volatile Fatty Acids}

In control goats before TSH treatment, the fractions of formic $(14.17 \mu \mathrm{g} / \mathrm{ml})$, acetic $(191.84 \mu \mathrm{g} / \mathrm{ml})$, propionic $(0.321 \mu \mathrm{g} / \mathrm{ml})$, iso-valeric $(0.605 \mu \mathrm{g} / \mathrm{ml})$, n-valeric $(0.2257 \mu \mathrm{g} / \mathrm{ml})$, iso-caproic $(0.4004 \mu \mathrm{g} / \mathrm{ml})$, n-caproic $(0.0222 \mu \mathrm{g} / \mathrm{ml})$ and heptanoic acid $(1.772 \mu \mathrm{g} / \mathrm{ml})$ were estimated. One hour post-TSH infusion, formic (45\%), acetic $(25 \%)$, propionic (45\%), iso-caproic $(23 \%)$ increased noticeably however, the elevation of n-caproic ((292\%) and heptanoic acid (60\%) was more pronounced while iso-valeric (24\%) and n-valeric acid (23\%) decreased slightly. The fraction of iso-butyric and n-butyric acid did not appear in the sample before and also after TSH administration.

The pretreatment sample of hypoinsulinemic goats showed the fractions of formic $(26.90 \mu \mathrm{g} / \mathrm{ml})$, acetic (199.03 $\mu \mathrm{g} / \mathrm{ml})$, propionic $(0.506 \mu \mathrm{g} / \mathrm{ml})$, iso-butyric $(0.097 \mu \mathrm{g} / \mathrm{ml})$, iso-valeric $(0.8084 \mu \mathrm{g} / \mathrm{ml})$, $\mathrm{n}$-valeric 

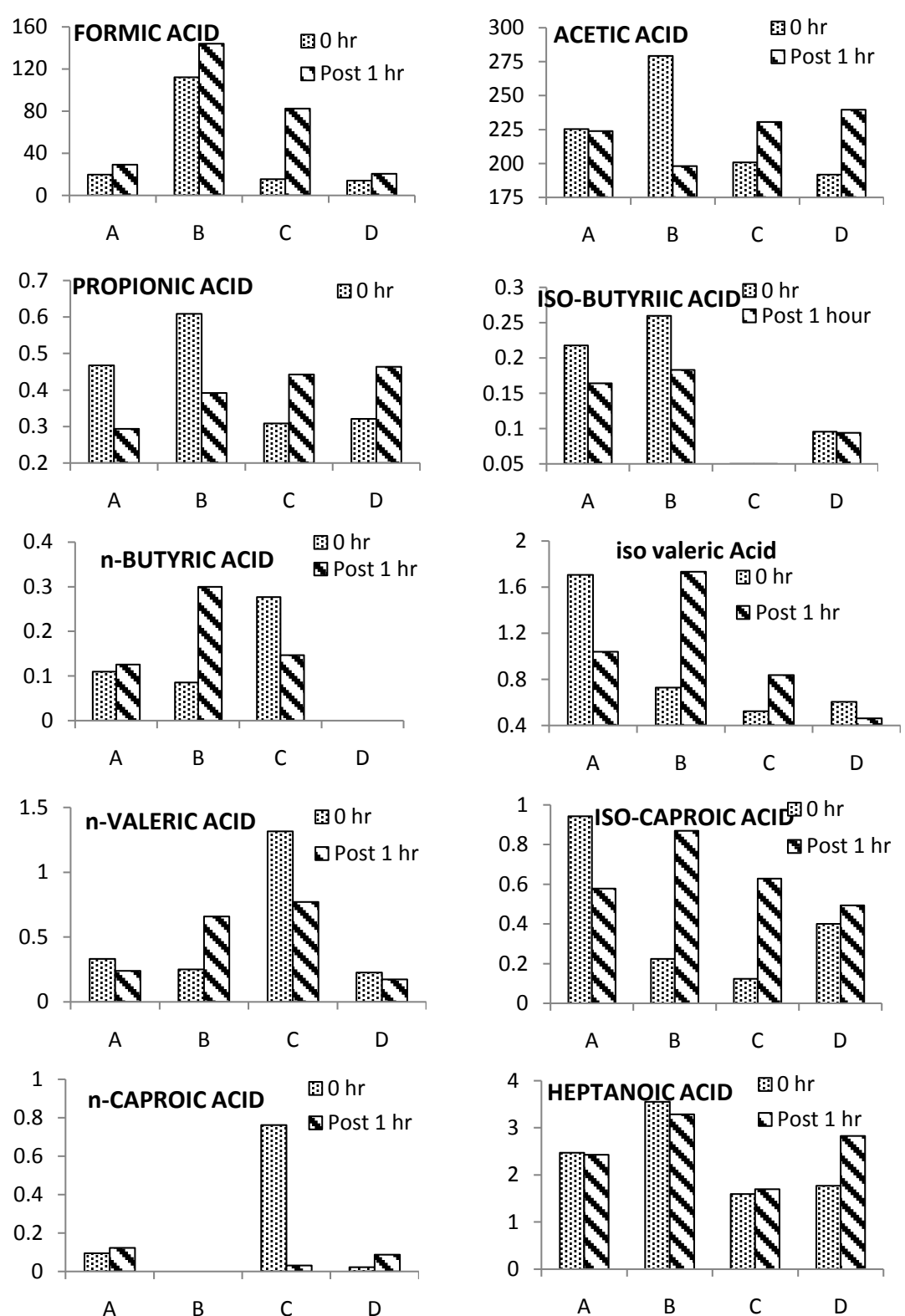

Figure 3. Plasma VFAs $(\mu \mathrm{g} / \mathrm{ml})$ before and 1 hour following TRH $(30 \mu \mathrm{g} / \mathrm{kg})$ and TSH $(2.5 \mathrm{ng} / \mathrm{kg})$ injection in intact and streptozotocin induced hypoinsulinemic. A: Control; B: TRH treated; C: Control; D: TSH treated.

(0.4961 $\mu \mathrm{g} / \mathrm{ml})$, iso-caproic $(0.53 \mu \mathrm{g} / \mathrm{ml})$, n-caproic $(0.0496 \mu \mathrm{g} / \mathrm{ml})$ and heptanoic acid $(2.779 \mu \mathrm{g} / \mathrm{ml})$. One hour after TSH infusion, formic, acetic, propionic, iso-butyric and iso-caproic acid almost remained in the pretreatment concentration range. The fractions of n-butyric (727\%), iso-valeric (150\%), n-valeric (158\%), n-caproic (125\%) and heptanoic acid (44\%) were, however, were enhanced markedly (Figure 3).

It is found that in hypoinsulinemia all the fractions, studied, have appeared in the samples and there had been mobilization of most of the fractions following TSH administration both in intact and hypoinsulinemic goats with comparatively greater response in the latter group.

\section{Discussion}

The present study is one of the parts of the investigations on hormonal interactions on metabolism in the goat as model of ruminants. Ruminants because of rumen digestion of the food to mostly volatile fatty acids (VFAs) are 
dependent for their glucose supply on hepatic gluconeogenesis from VFAs [19] [20]. Therefore ruminants exhibit insulin resistance to promote gluconeogenesis [21]. The pattern of insulin resistance in ruminants seems to be corresponding with insulin resistance in type 2 diabetes of non-ruminants. As type 2 diabetes is mainly characterized of insulin resistance [22]. Hypoinsulinemic diabetes was induced in the goats and various features had been studied to understand how insulin deficiency induces adaptations in these insulin resistant animals. In the present study the effects of thyroid regulatory and stimulatory hormones of TRH and TSH were studied on glucose utilization and specific lipid metabolism related to ruminants. Such study provides information on hormones' interaction and nutrient metabolism in these groups of animals and also may provide some insight on insulin resistance in type 2 diabetes mellitus in similar relationships.

Thyroid hormones have wide range effects on various metabolites including lipids specifically and are shown to improve lipid profile and reduce fat [23] and the hypothalamo-hypophyseal axis is well understood to regulate the release and synthesis of thyroid hormones [24]. Thyroid hormones have been directly administered to study their effects on various targets; however, it is appropriate that thyroid hormones are stimulated by indirect and direct thyrotrophic hormones of TRH and TSH respectively. That provides better understanding of thyroid hormones action in the physiological responses and the resultant adaptations in relation to other hormones and metabolites.

Streptozotocin is pancreatic beta cells cytotoxic thus since decades is employed for the induction of insulin deficient diabetes in experimental animals [25]. In the goats of the present study diabetes was induced successfully as monitored with glycemia. These were maintained for the various set of the experiments and one of the experiments of TRH and TSH infusion was conducted. The pertinent result of significance in glucose responses was its reduction in hypoinsulinemia compare to the intact goats. In TRH case its reduction was restored to normal in 24 hours after the dose conversely in TSH dose it remained reduced even 24 hours after the hormone infusion compared to the respective control goats. The greater expression of this glycemia response is very likely that TRH did not but TSH stimulated thyroid gland adequately. It is thus assumed that in the insulin deficient goats glucose is utilized in the hormones interactions. Thyroid hormones support the potential of hormonally inducing glucose transporter expression in insulin-resistant muscle as observed in NIDDM in rats [26]. It seems very likely with glucose lowering in hypoinsulinemic goats of the study as Weinstein et al. reported that thyroid hormone increases even basal glucose transport in skeletal muscle with GLUT4 glucose transporter expression [27]. These interpretations are pointing on probable role of thyroid hormones in the mechanism of insulin resistance and hyperglycemia.

Medium- and long-chain free fatty acids are energy source for whole body and biological metabolites and components. Therefore are important targets for the actions of metabolism affecting hormones such as insulin and thyroid hormones. In the present work TRH and TSH who in fact stimulate thyroid gland to release tetraand triiodothyronine caused mainly increases in different fractions of LCFAs in the intact goats. Some increases were prominent than the others. In hypoinsulinemic goats except one or two fractions of LCFAs most could not be detected in the sera. Following TRH and TSH doses almost all the fraction were estimated in sufficient amounts in the circulation. It appears that LCFAs are probably utilized in enhanced gluconeogenesis in glucose production resulting in hyperglycemia, however it appears that thyroid hormones stimulated by TRH and TSH inhibit the gluconeogenic enzymes and in their enhanced endogenous release hepatic glucose production from LCFAs is comparatively inhibited and their fractions were thus detected in the circulation. This assumption also explains the sustaining low glucose level in hypoinsulinemic goats following especially TSH administration. The LCFAs were not available for glucose production due to inhibition of gluconeogenic enzymes by stimulated thyroid hormones.

The results of volatile fatty acids resemble to those of long chain fatty acids. In insulin deficient goats both following TRH and TSH doses some fractions remained unaffected and the others were markedly elevated in the circulation. There was pronounced elevations of n-butyric (250\%), iso-valeric (138\%) n-valeric (164\%) and isocaproic acid (289\%) after TRH dose. Similarly the fractions of n-butyric (727\%), iso-valeric (150\%), n-valeric $(158 \%)$ and n-caproic (125\%) were enhanced tremendously one hour following TSH injection (Figure 3). It is proposed that like in the LCFAs, the volatile fractions of fatty acids also in insulin deficient state through endogenous stimulated thyroid hormones inhibit the mechanisms that utilize some volatile fraction in glucose production. This is more likely to be at the enzymatic level as gluconeogenic enzymes are interfered by the endogenously stimulated thyroid hormones to reduce glucose production which otherwise not observed to the same extent in intact goats. 


\section{Conclusion}

In conclusion the present study through the compromising results of glucose reduction and the marked increases in LCFAs and VFAs in hypoinsulinemic goats following endogenous thyroid hormones stimulation indicates the role of thyroid hormones in insulin resistant and hyperglycemia especially in goats. Weinstein et al. have reported that thyroid hormone increased even basal glucose transport in skeletal muscle with GLUT4 glucose transporter expression [27]. These interpretations are pointing on probable role of thyroid hormones in insulin resistance and hyperglycemia. It is very likely that such mechanism also prevails in non-ruminants including human and there is a need for further investigations.

\section{References}

[1] Larsen, P.R., Davies, T.F., Schlumberger, M.J. and Hay, I.D. (2008) Thyroid Physiology and Diagnostic Evaluation of Patients with Thyroid Disorders. In: Kronenberg, H.M., Melmed, S., Polonsky, S.K. and Larsen, P.R., Eds., Williams Textbook of Endocrinology, 11th Edition, Section III, Chapter 10, Saunders Elsevier, Philadelphia, 715-717.

[2] Koo, K.B., Suh, H.J., Ra, K.S. and Choi, J.W. (2011) Protective Effect of Cyclo(his-pro) on Streptozotocin-Induced Cytotoxicity and Apoptosis in Vitro. Journal of Microbiology and Biotechnology, 21, 218-227. http://dx.doi.org/10.4014/jmb.1012.12003

[3] Weekes, T.E.C. (1992) Influence of Experimental Hyperthyroidism on Insulin Action in Growing Sheep. Metabolism, 41, 246-252. http://dx.doi.org/10.1016/0026-0495(92)90266-D

[4] Nudda, A., Battacone, G., Atzori, A.S., Dimauro, C., Rassu, S.P.G., Nicolussi, P. and Pulina, G. (2013) Effect of Extruded Linseed Supplementation on Blood Metabolic Profile and Milk Performance of Saanen Goats. Animal, 7, 1464-1471. http://dx.doi.org/10.1017/S1751731113000931

[5] Bagchi, N., Palaniswami, N., Desai, H., Felicetta, J. and Brown, T.R. (1988) Decreased Thyroidal Response to Thyrotropin in Type II Diabetes Mellitus. Metabolism, 37, 669-671. http://dx.doi.org/10.1016/0026-0495(88)90088-1

[6] Toscano, G.P., Lazzaroni, C., Gallo, S. and Galeazzi, D. (1993) Research on Muscle Hypertrophy in Beef Cattle: Thyroid Hormones. In: Proceedings of the 10th National Congress, Scientific Association of Anim. Prod., Bologna, 311-315.

[7] Kaske, M., Elmahdi, B., Von Engelhardt, W. and Sallmann, H.P. (2001) Insulin Responsiveness of Sheep, Ponies, Miniature Pigs and Camels: Results of Hyperinsulinemic Clamps Using Porcine Insulin. Journal of Comparative Physiology B, 171, 549-556. http://dx.doi.org/10.1007/s003600100205

[8] Mei, S., Yang, X., Guo, H., Gu, H., Zha, L., Cai, J., Li, X., Liu, Z., Bennett, B.J., He, L. and Cao, W. (2014) A Small Amount of Dietary Carbohydrate Can Promote the HFD-Induced Insulin Resistance to a Maximal Level. PLoS One, 9, eCollection.

[9] Allen, M.S., Bradford, B.J. and Oba, M. (2009) Board Invited Review: The Hepatic Oxidation Theory of the Control of Feed Intake and Its Application to Ruminants. Journal of Animal Science, 87, 3317-3334.

[10] Kabadi, U.M. (1984) Impaired Pituitary Thyrotroph Function in Uncontrolled Type II Diabetes Mellitus: Normalization on Recovery. Journal of Clinical Endocrinology and Metabolism, 59, 521-525. http://dx.doi.org/10.1210/jcem-59-3-521

[11] Wrutniak, C., Cabello, G., Charrier, J., Dulor, J.P., Blanchard, M. and Barenton, B. (1987) Effects of TRH and GRF Administration on GH, TSH, T4 and T3 Secretion in the Lamb. Reproduction Nutrition Development, 27, 501-510. http://dx.doi.org/10.1051/rnd:19870406

[12] Dahl, G.E., Evans, N.P., Thrun, L.A. and Karsch, F.J. (1994) A Central Negative Feedback Action of Thyroid Hormones on Thyrotropin-Releasing Hormone Secretion. Endocrinology, 135, 2392-2397.

[13] Krueger, T. and Melendez, P. (2012) Effect of Ghrelin on Feed Intake and Metabolites in Lambs. Appetite, 58, 758-759. http://dx.doi.org/10.1016/j.appet.2012.01.013

[14] Remely, M., Aumueller, E., Merold, C., Dworzak, S., Hippe, B., Zanner, J., Pointner, A., Brath, H. and Haslberger, A.G. (2014) Effects of Short Chain Fatty Acid Producing Bacteria on Epigenetic Regulation of FFAR3 in Type 2 Diabetes and Obesity. Gene, 37, 85-92. http://dx.doi.org/10.1016/j.gene.2013.11.081

[15] Barham, D. and Trinder, P. (1972) Improved Color Reagent for the Determination of Blood Glucose by the Oxidase System. Analyst, 97, 142-145. http://dx.doi.org/10.1039/an9729700142

[16] Falholt, K., Lund, B. and Falholt, W. (1973) Easy Micromethod for Routine Determination of Free Fatty Acids in Plasma. Clinica Chimica Acta, 46, 105-111.

[17] Morrison, W.R. and Smith, L.M. (1964) Preparation of Fatty Acid Methyl Esters and Dimethylacetals from Lipids with Boron Fluoride-Methanol. Journal of Lipid Research, 5, 600-608. 
[18] Remsey, C. and Demigne, C. (1974) Determination of Volatile Fatty Acids in Plasma after Ethanolic Extraction. Biochemical Journal, 141, 85-91.

[19] Bergman, E.N. (1990) Energy Contributions of Volatile Fatty Acids from the Gastrointestinal Tract in Various Species. Physiological Reviews, 70, 567-590.

[20] Young, J.W. (1977) Gluconeogenesis in Cattle: Significance and Methodology. Journal of Dairy Science, 60, 1-15. http://dx.doi.org/10.3168/jds.S0022-0302(77)83821-6

[21] Donkin, S.S. and Armentano, L.E. (1995) Insulin and Glucagon Regulation of Gluconeogenesis in Preruminating and Ruminating Bovine. Journal of Animal Science, 73, 546-551.

[22] Kahn, S.E., Hull, R.L. and Utzschneider, K.M. (2006) Mechanisms Linking Obesity to Insulin Resistance and Type 2 Diabetes. Nature, 444, 840-846. http://dx.doi.org/10.1038/nature05482

[23] Baxter, J.D. and Webb, P. (2009) Thyroid Hormone Mimetics: Potential Applications in Atherosclerosis, Obesity and Type 2 Diabetes. Nature Reviews Drug Discovery, 8, 308-320. http://dx.doi.org/10.1038/nrd2830

[24] Fonseca, T.L., Correa-Medina, M., Campos, M.P., Wittmann, G., Werneck-de-Castro, J.P., Arrojo, E., Drigo, R., Mora-Garzon, M., Ueta, C.B., Caicedo, A., Fekete, C., Gereben, B., Lechan, R.M. and Bianco, A.C. (2013) Coordination of Hypothalamic and Pituitary T3 Production Regulates TSH Expression. Journal of Clinical Investigation, 123, 14921500.

[25] Kim, Y.T. and Steinberg, C. (1984) Immunologic Studies on the Induction of Diabetes in Experimental Animals. Cellular Basis for the Induction of Diabetes by Streptozotocin. Diabetes, 33, 771-777. http://dx.doi.org/10.2337/diab.33.8.771

[26] Torrance, C.J., Devente, J.E., Jones, J.P. and Dohm, G.L. (1997) Effects of Thyroid Hormone on GLUT4 Glucose Transporter Gene Expression and NIDDM in Rats. Endocrinology, 138, 1204-1214. http://dx.doi.org/10.1210/endo.138.3.4981

[27] Weinstein, S.P., O’boyle, E. and Haber, R.S. (1994) Thyroid Hormone Increases Basal and Insulin-Stimulated Glucose Transport in Skeletal Muscle. The Role of GLUT4 Glucose Transporter Expression. Diabetes, 43, 1185-1189. http://dx.doi.org/10.2337/diab.43.10.1185 
Scientific Research Publishing (SCIRP) is one of the largest Open Access journal publishers. It is currently publishing more than 200 open access, online, peer-reviewed journals covering a wide range of academic disciplines. SCIRP serves the worldwide academic communities and contributes to the progress and application of science with its publication.

Other selected journals from SCIRP are listed as below. Submit your manuscript to us via either submit@scirp.org or Online Submission Portal.
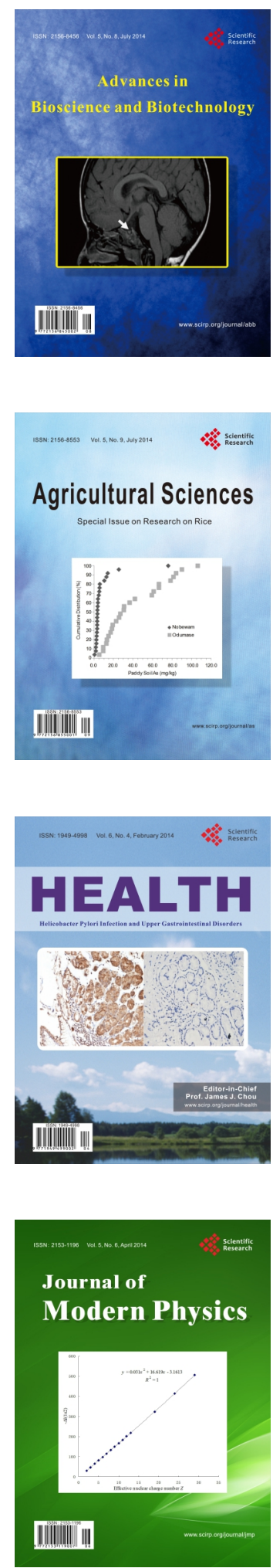
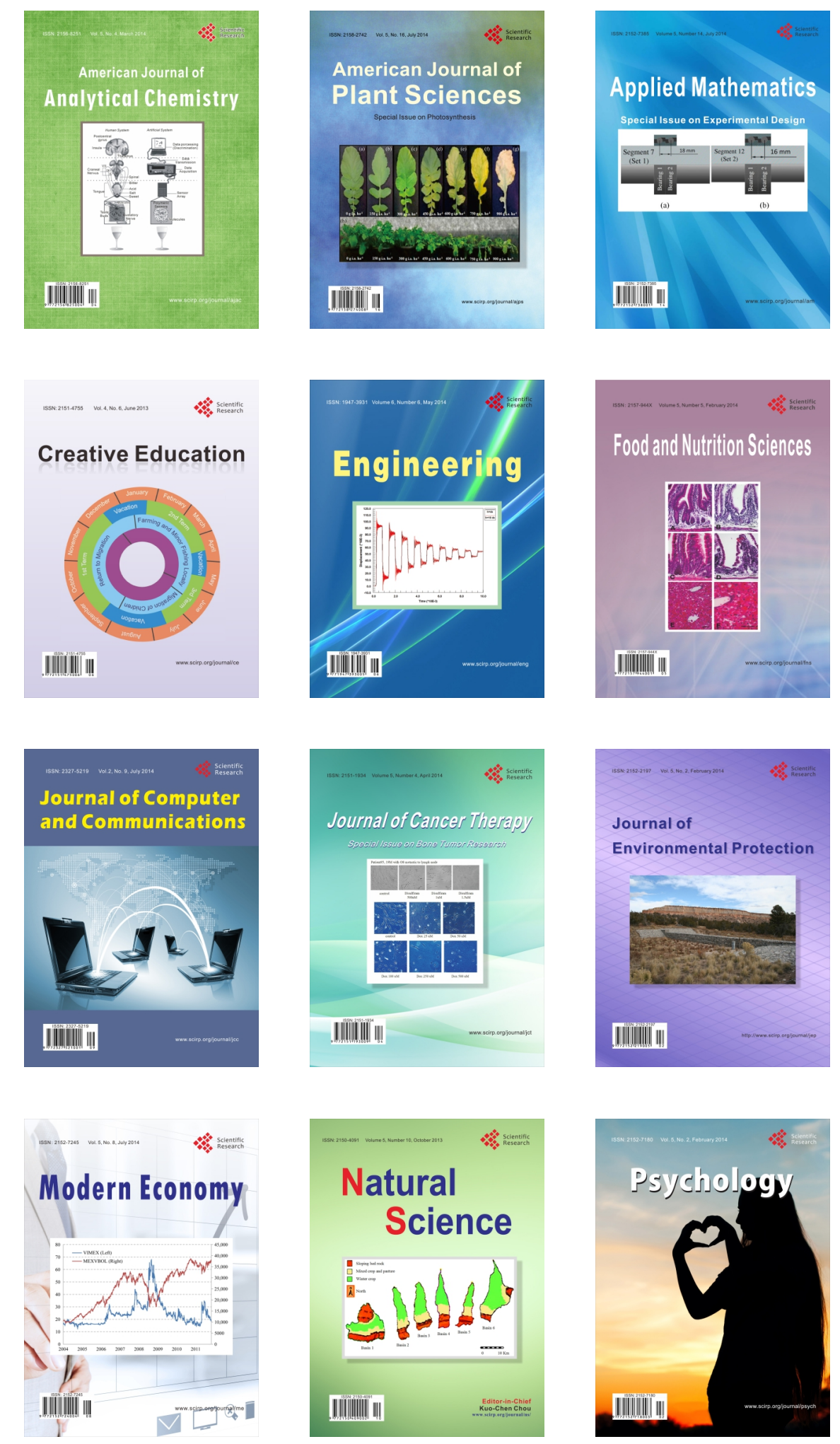